\title{
Anti-inflammatory and anti-nociceptive potentials of Salacia lehmbachii leaves
}

\author{
Augustine D. Essien ${ }^{1^{*}}$, Grace A. Essiet ${ }^{1}$, Godwin C. Akuodor ${ }^{2}$, Edidara E. Thomas ${ }^{3}$ and \\ Francis V. Udoh ${ }^{1}$
}

\author{
1Department of Pharmacology, College of Medical Sciences, University of Calabar, Nigeria. \\ ${ }^{2}$ Department of Medical Laboratory Sciences, Ebonyi State University, Abakaliki, Nigeria. \\ ${ }^{3}$ Department of Pathology, University of Uyo, Uyo, Nigeria. \\ *Corresponding author. Email: augprogclinic@yahoo.com, augessien@unical.edu.ng
}

Copyright (C) 2017 Essien et al. This article remains permanently open access under the terms of the Creative Commons Attribution License 4.0, which permits unrestricted use, distribution, and reproduction in any medium, provided the original work is properly cited.

Received 5th September, 2017; Accepted 25th September, 2017

\begin{abstract}
For decades, the leaves of Salacia lehmbachii Loes (SL), which belong to the family of Celastraceae are acceptably used in south-eastern parts of Nigeria in traditional medicine for the treatment of fever and painful conditions. This study assessed the anti-inflammatory and anti-nociceptive effects of its water extracts on inflammation and nociception in rats. Doses of 100,200 and $400 \mathrm{mg} / \mathrm{kg}$ of water extract of $S L$ were used in elucidating anti-inflammatory activities in Wistar rats and mice by using carrageenan, egg albumin-induced paw and xylene-induced ear oedema; while acetic acid-induced writhing/abdominal muscle constriction, formalin-induced nociception and tail immersion models were used for analgesic study. In each study, 30 animals were randomly selected and grouped into five with six animals per group. Group 1 (control) received $20 \mathrm{~mL} / \mathrm{kg}$ of distilled water; groups 2 to 4 received 100, $200 \mathrm{and} 400 \mathrm{mg} / \mathrm{kg}$ of the extract respectively; while group 5 received $150 \mathrm{mg} / \mathrm{kg}$ of aspirin and $10 \mathrm{mg} / \mathrm{kg}$ of morphine (tail immersion study). The $\mathrm{ED}_{50}$ of the water extract was $200 \mathrm{mg} / \mathrm{kg}$. The water extract of the $S L$ leaves showed significant $(p<0.05)$ dosedependent effects in all the parameters. Doses of 200 and $400 \mathrm{mg} / \mathrm{kg}$ showed comparable effects to those effects exhibited by the respective positive controls: - aspirin (anti-inflammatory study); aspirin and morphine (analgesic study). The water extract of the $S L$ leaves possesses potent anti-inflammatory and analgesic properties. The results justify the claim by the herbalists and its use in folkloric medicines for pains and conditions associated with pains.
\end{abstract}

Keywords: Egg-albumin, herbal remedies, inflammation, carrageenan, analgesics, water extract, xylene.

\section{INTRODUCTION}

Inflammation and pains are usually symptoms implicated in many various clinical presentations irrespective of the causative factors (Dhara et al., 2000). The reaction to these phenomena is characteristic responses by all living tissues. It is complex and is brought about by various mediators such as histamine, prostaglandins $\mathrm{E}_{2}$ and $\mathrm{I}_{2}$ that are synthesized as a result of the interaction of the noxious substances or micro-organisms with the tissue (Barnes and Karin, 1998; Ganesh et al., 2008). Release of cascade of inflammatory mediators makes inflammatory reaction to involve both vascular and cellular components (Luster, 1998; Akuodor et al., 2015).

Plants synthesize substances that are meant to defend against varieties of predators. These substances (phytochemicals), when extracted, may be useful in not only alleviating human health problems but maintaining human health (Huffman, 2003; Lai and Roy, 2004). Before the advent of synthetic drugs, humans were completely dependent on plants as sources of medicine for curing diseases (Elujoba et al., 2005; Tapsel et al., 2006). Extracted substances obtained from several different plants are increasingly and widely used by traditional healers in Nigeria (Okokon and Nwafor, 2010). The World Health Organization (WHO) estimated that about $80 \%$ of the world's population often depended on herbal medicines and hence advocated the inclusion of plants' source in primary health care due to their great potentials (WHO, 2006). These extracted constituents 
from many plants and their products have proven to exhibit biological and pharmacological activities such as anti-inflammatory, antipyretic, antiviral, and other effects (Hakiman and Maziah, 2009). Despite the use of several anti-inflammatory agents, people still resort to the traditional folkloric medicine using some plant extract.

One such plants is Salacia lehmbachii Loes (Celastraceae) (SL) that is a shrub-like to small tree of about $3 \mathrm{~m}$ high (Willcox and Bodeker, 2004). It is widely distributed in the tropical rain forest of West, Central and East Africa. In South Eastern Nigeria, its decoctions from roots and leaves are commonly used by traditional healers for treatment of different diseases such as renal dysfunction, fever, pain and gastrointestinal disorders (Essien et al., 2015a, 2016a). The root extracts showed no hepatic toxicity but improves hematopoietic processes (Essiet et al., 2016a, 2016b). This study therefore investigates the anti-inflammatory and analgesic activities of Salacia lehmbachii leaves using experimental animal models.

\section{MATERIALS AND METHODS}

\section{Preparation of plant extract}

Salacia lehmbachii was collected from Oruk Otong village in Ukanafun Local Government Area of Akwa Ibom state, Nigeria, in the month of November, 2014. It was identified and authenticated by a taxonomist, Mr. Frank Apojoye, of the Department of Botany, University of Calabar, Nigeria, where a voucher specimen (No. 688) was kept for reference. The leaves were wash-cleaned and air-dried at room temperature for 10 to 15 days in a clean and dry laboratory environment (Pharmacology Department, University of Calabar). The leaves were sliced and crushed into coarse powder using pestle and mortar. The dry coarse leaf powder (495 g) was defatted by distilling with petroleum ether (May \& Baker Ltd, Dagenham, England) and thereafter, extracted in water using Soxhlet extractor (Friedrich Polzime, England). The distillate from water extraction was concentrated to dryness in a hot oven (Grieve Lab. Oven, Model LR 271C, Grieve Co-op. Ltd, IL, USA) at $40^{\circ} \mathrm{C}$. The dry matter obtained $(26.4 \%$ $\mathrm{w} / \mathrm{w})$ was stored in an air-tight container till when it was reconstituted for the experiment and kept in a refrigerator at $4^{\circ} \mathrm{C}$ throughout the study period.

\section{Phytochemical Screening}

The qualitative phytochemical screening of the water extract of the leaves of Salacia lehmbachii was carried out according to standard methods (Sofowora, 1993; Mukherjee, 2006).

\section{Experimental animals}

Healthy adult Wistar rats (150 to190 g) and mice (18 to $22.5 \mathrm{~g}$ ) of both male and female sexes were obtained from the animal house, Department of Pharmacology, College of Medical Sciences, University of Calabar. Nigeria. The animals were kept in cages in the environment that provided 12:12 $\mathrm{h}$ light/dark cycle and good ventilation. They had free access to standard feed (Growers mash from Agro Feed Nigeria Plc, Calabar) and tap water ad libitum. Approval for the study was obtained from the Faculty of Basic Medical Science, Animal Research Ethics Committee, University of Calabar (ETHIC REF NO: 025PA30517).

\section{Acute toxicity test}

The acute toxicity test of the water extract of Salacia lehmbachii leaves was determined using randomly selected mice of both sexes following OECD guidelines (2010) and Ghosh (2005). The procedure as reported by Essien et al. (2016b) was adopted.

\section{Effective dose}

The $\mathrm{ED}_{50}$ of the water extract of Salacia lehmbachii leaves was determined using traditional dose response procedure (with slight modification) described by Ahmad et al. (2011). Thirty rats of both sexes were divided into ten groups with 3 rats per group. Pyrexia was induced in each rat with subcutaneous administration of $10 \mathrm{~mL} / \mathrm{kg}$ of dinitrophenol. Thirty minutes after, group 1 received orally $20 \mathrm{~mL} / \mathrm{kg}$ of distilled water; while groups 2 to 10 received orally graded doses of $50,100,150,200,250,300,350$, 400 , and $450 \mathrm{mg} / \mathrm{kg}$ of the water extract respectively. Thereafter, rectal temperature was recorded at $30 \mathrm{~min}$ interval and for $3 \mathrm{~h}$. The response (percentage inhibition of pyrexia by the extract) was plotted against the log dose.

\section{Anti-inflammation study}

\section{Carrageenan-induced inflammatory oedema}

The modified methods of Akah and Nwabie (1994) and Ravelo et al. (2011) were used. Randomly selected adult Wistar rats of both sexes were divided into 5 groups of 6 rats in each cage. Group 1 and Group 5 received orally $20 \mathrm{~mL} / \mathrm{kg}$ of distilled water and $150 \mathrm{mg} / \mathrm{kg}$ of aspirin respectively while Groups 2, 3 and 4 received orally corresponding doses of 100,200 and $400 \mathrm{mg} / \mathrm{kg}$ of water extract of Salacia lehmbachii leaves respectively. After 30 min of administration, the initial size of the right hind paw of each rat was measured using caliper (Letica 7500, Spain) before inducing paw oedema in each rat by injecting $0.5 \mathrm{~mL}$ of $1 \%$ carrageenan (Sigma Chemical Co, St. Louis, MO, USA) into the sub-plantar of the right hind paw of each rat. After this phlogesic (carrageenan) treatment, the circumference (size) of the affected right hind paw was measured and recorded at interval of 30 $\min$ and for $2 \mathrm{~h}$. 


\section{Egg-albumin-induced inflammation in rats}

The method described by Akah and Nwabie (1994), AlGhamdi, (2001) and Xu et al. (2014) with little modification was adopted for this study. Thirty adult Wistar rats of both sexes were randomly selected and grouped into 5 with 6 rats per cage. Groups 1 and 5 received orally $20 \mathrm{~mL} / \mathrm{kg}$ of distilled water and $150 \mathrm{mg} / \mathrm{kg}$ of aspirin respectively while Groups 2, 3 and 4 received orally 100,200 and $400 \mathrm{mg} / \mathrm{kg}$ of the water extract respectively. After $30 \mathrm{~min}$, the initial volume (size) of their right hind paw was measured and recorded before inducing an inflammatory oedema by injecting subcutaneously $0.2 \mathrm{~mL}$ of fresh egg-albumin into the subplantar of the right hind paw. The right-paw volumes were measured and recorded at 30 min intervals and for $2 \mathrm{~h}$ using Calliper (Letica 7500, Spain).

\section{Xylene-induced ear oedema in albino mice}

The methods of Hosseinzedeh and Younesi (2002) and Jumping et al. (2005) were adopted for this study. Thirty randomly selected adult albino mice were grouped into 5 of 6 mice per cage. Mice from Groups 2, 3 and 4 were treated orally with doses of 100,200 and $400 \mathrm{mg} / \mathrm{kg}$ of water extract of Salacia lehmbachii leaves respectively while Groups 1 and 5 received orally $20 \mathrm{~mL} / \mathrm{kg}$ of distilled water and $150 \mathrm{mg} / \mathrm{kg}$ of aspirin respectively. After $30 \mathrm{~min}$, two drops of dimethylbenzene (xylene) were instilled into the right ear of each mouse in the test groups and controls to induce inflammatory oedema. Three hours post oedema induction, under light anesthesia, all the mice were sacrificed, and both ears (treated right and untreated left ears) were severed, weighed and the difference in weight which indicated the extent of oedema was recorded.

\section{Analgesic study}

\section{Acetic acid-induced writhing test}

The analgesic activity of water extract of $S$. lehmbachii leaves was carried out according to procedures adopted by Singh and Majumbar (1995) and Akuodor et al. (2011) on acetic acid-induced writhing. Thirty randomly selected adult albino mice were divided into 5 groups of 6 mice per cage and were subjected to $24 \mathrm{~h}$ fast but access to water was not restricted. Groups 1 and 5 received orally 20 $\mathrm{mL} / \mathrm{kg}$ of distilled water and $150 \mathrm{mg} / \mathrm{kg}$ of aspirin respectively while group 2, 3 and 4 received orally 100 , 200 and $400 \mathrm{mg} / \mathrm{kg}$ of the water extract of Salacia lehmbachii leaves respectively. After $30 \mathrm{~min}$, each mouse was administered intraperitoneally $20 \mathrm{~mL} / \mathrm{kg}$ of $0.7 \%$ acetic acid to induce pain sensation. Each mouse was later placed in a transparent observation chamber. Five minutes post acetic acid administration, each mouse was carefully observed for the number of abdominal constrictions or writhing behavior for $30 \mathrm{~min}$.

\section{Formalin-induced nociception}

The procedure was carried out according to methods by Tjolsen et al. (1993) and Bachhav et al. (2009). Thirty healthy adult albino rats were randomly selected and divided into 5 groups of 6 rats per cage. They were subjected to $24 \mathrm{~h}$ fast with access to drinking water. Groups 2, 3 and 4 received orally 100, 200 and 400 $\mathrm{mg} / \mathrm{kg}$ of water extract of Salacia lehmbachii leaves respectively while groups 1 and 5 received orally 20 $\mathrm{mL} / \mathrm{kg}$ of distilled water and $150 \mathrm{mg} / \mathrm{kg}$ of aspirin respectively. After 30 min interval, pain was induced by injecting 50 micro-liter of formalin (2.5\% solution) into the sub-plantar of the left hind paw of all the rats. Each rat was placed in an observation chamber (transparent animal cage) for assessment of anti-nociceptive effect which was based on counting the frequency and scoring the severity of pain using the following scales: $0=$ rats were able to walk or stand firmly on the injected paw; $1=$ the injected paw was favored (able to walk to some extent) or partially elevated; 2 = the injected paw was clearly lifted off the floor; $3=$ the rats licked, chewed or shook the injected paw (Tjolsen et al.,1993).

\section{Tail immersion test}

The method described by Ramabadran et al. (1989) and Akuodor et al. (2015) was used for this study. Thirty adult mice were randomly selected and grouped into 5 groups of 6 mice in each cage. All were subjected to $24 \mathrm{~h}$ fast while water was freely given. Groups 1 and 5 which served as controls were respectively treated with 20 $\mathrm{mL} / \mathrm{kg}$ of distilled water orally and $10 \mathrm{mg} / \mathrm{kg}$ of morphine subcutaneously while groups 2,3 and 4 received orally 100,200 and $400 \mathrm{mg} / \mathrm{kg}$ of the water extract respectively. After 30 min interval of drug treatment, each mouse was kept in restrainer cage (Grieve Cooperation, IL, U.S.A.), leaving the tail hung out and freely exposed to be dipped in a water bath with maintained temperature at $52 \pm 1^{\circ} \mathrm{C}$. The duration of stay of the tail in the bath before withdrawing its tail out of the water was recorded. The latency was evaluated at 30,60, 90 and $120 \mathrm{~min}$.

\section{Statistical analysis}

Results were express as mean \pm S.E.M. Analysis of data was done using one-way ANOVA followed by NeumanKeuls post hoc test where $F$ value was significant. A p value of less than 0.05 was considered significant.

\section{RESULTS}

Phytochemical screening of the water extract of the 
Table1. Phytochemical constituents of the water extract of $S$. lehmbachii leaves.

\begin{tabular}{lc}
\hline Phytochemical & Quantity \\
\hline Carbohydrates & + \\
Reducing sugars & - \\
Saponins & ++ \\
Steroids & ++ \\
Flavonoids & ++ \\
Alkaloids & ++ \\
Terpenoids & ++ \\
Anthraquinones & + \\
Resins & + \\
Balsams & + \\
Tannins & ++ \\
\hline
\end{tabular}

Table 2. Effect of water extract of SL leaves on carrageenan-induced paw edema in rats.

\begin{tabular}{|c|c|c|c|c|c|c|c|c|}
\hline \multirow{2}{*}{ Treatment } & \multirow{2}{*}{ Dose(mg/kg) } & \multicolumn{7}{|c|}{ Post treatment Paw edema diameter $(\mathrm{mm})$ at hourly interval } \\
\hline & & $\mathbf{O} \mathbf{h}$ & $0.5 \mathrm{~h}$ & $1 \mathrm{~h}$ & $2 \mathrm{~h}$ & $3 \mathrm{~h}$ & $4 \mathrm{~h}$ & $5 \mathrm{~h}$ \\
\hline \multirow[t]{2}{*}{ Distilled water } & $20 \mathrm{~mL} / \mathrm{kg}$ & $1.24 \pm 0.05$ & $2.69 \pm 0.07$ & $2.83 \pm 0.01$ & $2.86 \pm 0.02$ & $2.78 \pm 0.03$ & $2.78 \pm 0.02$ & $2.78 \pm 0.05$ \\
\hline & 100 & $1.24 \pm 0.01$ & $2.68 \pm 0.05$ & $2.68 \pm 0.01^{*}$ & $2.33 \pm 0.05^{*}$ & $2.18 \pm 0.06^{*}$ & $2.09 \pm 0.05^{\star}$ & $1.96 \pm 0.06$ \\
\hline \multirow[t]{2}{*}{ S. lehmbachii } & 200 & $1.29 \pm 0.02$ & $1.59 \pm 0.03^{*}$ & $1.40 \pm 0.02^{*}$ & $1.31 \pm 0.03^{*}$ & $1.31 \pm 0.06^{*}$ & $1.30 \pm 0.03^{*}$ & $1.30 \pm 0.06$ \\
\hline & 400 & $1.29 \pm 0.01$ & $1.71 \pm 0.06^{*}$ & $1.31 \pm 0.02^{*}$ & $1.29 \pm 0.05^{\star}$ & $1.29 \pm 0.03^{*}$ & $1.27 \pm 0.01^{*}$ & $1.26 \pm 0.03^{\star}$ \\
\hline Aspirin & 150 & $1.26 \pm 0.01$ & $1.51 \pm 0.05^{*}$ & $1.26 \pm 0.02^{*}$ & $1.26 \pm 0.03^{*}$ & $1.26 \pm 0.02^{*}$ & $1.26 \pm 0.01^{*}$ & $1.26 \pm 0.01$ \\
\hline
\end{tabular}

Data are express as mean $\pm \operatorname{SEM}(n=6)$; *significantly different from control at $p<0.05$.

leaves revealed the presence of saponins, flavonoids, steroids, terpenoids, alkaloids and tannins among others (Table 1).

\section{Acute toxicity test}

Oral administration of graded concentration of the water extract of Salacia lehmbachii leaves did not exhibit any lethality nor any sign of toxicity in the experimental mice.

\section{Effective dose}

The result showed that $E_{50}$ of the water extract of Salacia lehmbachii leaves was $200 \mathrm{mg} / \mathrm{kg}$; hence doses of 100,200 and $400 \mathrm{mg} / \mathrm{kg}$ were conveniently used.

\section{Carrageenan/Egg albumin-induced oedemata}

The water extract of Salacia lehmbachii leaves showed significantly $(p<0.05)$ dose-related inhibition of the paw oedema induced by both carrageenan and egg-albumin when compared to control as shown in Tables 2 and 3 respectively. The resultant anti-inflammatory effect of the water extract was observed after $30 \mathrm{~min}$ and was significantly comparable to aspirin $(150 \mathrm{mg} / \mathrm{kg})$ in both parameters.

\section{Xylene-induced Ear oedema}

The inflammatory oedema induced in the mice ear was significantly $(p<0.05)$ inhibited by the water extract of Salacia lehmbachii leaves in a dose-dependent manner. The high (63 and 84\%) inhibition of the ear oedema (Table 4) was observed with doses of 200 and $400 \mathrm{mg} / \mathrm{kg}$ of the water extract respectively. The anti-inflammatory effect was comparable to effect produced by aspirin as shown in Table 4.

\section{Acetic acid-inducing writhing in mice}

The water extract of Salacia lehmbachii leaves at doses of 100 to $400 \mathrm{mg} / \mathrm{kg}$ exhibited significantly $(p<0.05)$ dosedependent reduction of abdominal contractions in mice. The doses of 200 and $400 \mathrm{mg} / \mathrm{kg}$ of this extract produced high (76.5 and $86.9 \%)$ suppression of contractions, and this analgesic effect is comparable to the effect produced by aspirin (Table 5 ). 
Table 3. Effect of water extract of $S L$ leaves on egg albumin-induced paw edema in rats.

\begin{tabular}{|c|c|c|c|c|c|c|}
\hline \multirow{2}{*}{ Treatments } & \multirow{2}{*}{ Dose $(\mathrm{mg} / \mathrm{kg})$} & \multicolumn{5}{|c|}{ Paw edema diameter $(\mathrm{mm})$ at $30 \mathrm{~min}$ interval } \\
\hline & & $0 \min$ & $30 \mathrm{~min}$ & $60 \mathrm{~min}$ & $90 \mathrm{~min}$ & $120 \mathrm{~min}$ \\
\hline \multirow[t]{2}{*}{ Distilled water } & $20 \mathrm{ml} / \mathrm{kg}$ & $1.33 \pm 0.02$ & $2.64 \pm 0.21$ & $2.94 \pm 0.21$ & $2.99 \pm 0.03$ & $2.90 \pm 0.19$ \\
\hline & 100 & $1.31 \pm 0.05$ & $2.60 \pm 0.03$ & $2.33 \pm 0.06^{*}$ & $2.28 \pm 0.05^{*}$ & $2.19 \pm 0.03^{*}$ \\
\hline \multirow[t]{2}{*}{ S.lehmbachii } & 200 & $1.30 \pm 0.03$ & $1.76 \pm 0.06^{*}$ & $1.31 \pm 0.04^{*}$ & $1.27 \pm 0.04^{*}$ & $1.27 \pm 0.02^{*}$ \\
\hline & 400 & $1.26 \pm 0.01$ & $1.89 \pm 0.03^{*}$ & $1.38 \pm 0.02^{*}$ & $1.29 \pm 0.04^{*}$ & $1.27 \pm 0.03^{*}$ \\
\hline Aspirin & 150 & $1.31 \pm 0.03$ & $1.98 \pm 0.01^{*}$ & $1.35 \pm 0.02^{*}$ & $1.32 \pm 0.02^{*}$ & $1.31 \pm 0.01^{*}$ \\
\hline
\end{tabular}

Data are express as mean $\pm \operatorname{SEM}(n=6)$; * significantly different from control at $p<0.05$.

Table 4. Effect of water extract of $S L$ leaves on xylene-induced ear edema in albino mice.

\begin{tabular}{lccccc}
\hline \multirow{2}{*}{ Treatments } & \multirow{2}{*}{ Dose $(\mathbf{m g} / \mathbf{k g})$} & \multicolumn{2}{c}{ Weight of mice ear $(\mathbf{m g})$} & $\begin{array}{c}\text { weight difference } \\
\text { (edema) }\end{array}$ & \% inhibition \\
\hline Distilled water & $20 \mathrm{ml} / \mathrm{kg}$ & $0.063 \pm 0.00$ & $0.130 \pm 0.01$ & $0.067 \pm 0.00$ & -- \\
& 100 & $0.072 \pm 0.00$ & $0.107 \pm 0.00$ & $0.035 \pm 0.00$ & $48^{\star}$ \\
S. lehmbachii & 200 & $0.070 \pm 0.01$ & $0.095 \pm 0.00$ & $0.025 \pm 0.01$ & $63^{\star}$ \\
& 400 & $0.065 \pm 0.01$ & $0.076 \pm 0.00$ & $0.011 \pm 0.01$ & $84^{\star}$ \\
Aspirin & 150 & $0.071 \pm 0.00$ & $0.081 \pm 0.01$ & $0.010 \pm 0.01$ & $85^{\star}$ \\
\hline
\end{tabular}

Data are express as mean \pm SEM $(n=6)$; * significantly different from control at $p<0.05$.

Table 5. Effect of water extract of $S L$ leaves on acetic acid-induced abdominal constrictions in mice.

\begin{tabular}{lccc}
\hline Treatments & Dose $\mathbf{( m g / k g})$ & Abdominal constrictions & \%Inhibition \\
\hline Distilled water & $20 \mathrm{ml} / \mathrm{kg}$ & $30.6 \pm 0.81$ & 0.00 \\
& 100 & $21.2 \pm 0.37^{*}$ & $30.7^{\star}$ \\
S. lehmbachii & 200 & $7.2 \pm 0.33^{*}$ & $76.5^{\star}$ \\
& 400 & $4.0 \pm 0.32^{*}$ & $86.9^{*}$ \\
Aspirin & 150 & $3.8 \pm 0.37^{*}$ & $87.6^{*}$ \\
\hline
\end{tabular}

Data are expressed as mean \pm SEM $(n=6)$; ${ }^{*}$ significantly different from control at $p<0.05$.

\section{Formalin-induced nociception}

The water extract of Salacia lehmbachii leaves significantly $(p<0.05)$ produced dose-related analgesic effect in formalin-induced pain in the rats. The extent of its analgesic effect shown high (71.4 and 85.7\%) inhibition of induced-pain with doses of 200 and 400 $\mathrm{mg} / \mathrm{kg}$ of the water extract respectively. The result is comparable to that exhibited by aspirin (Table 6).

\section{Tail immersion}

The water extract of Salacia lehmbachii leaves significantly $\quad(p<0.05) \quad$ produced dose-dependent protection of the animals from the heat stimuli of the hotbath. The protection of mice from heat stimuli started from 30 min post treatment with doses of 200 and 400 $\mathrm{mg} / \mathrm{kg}$ and maintained throughout the study period. The dose of $400 \mathrm{mg} / \mathrm{kg}$ of the extract produced effect similar to that produced by $10 \mathrm{mg} / \mathrm{kg}$ of morphine while mice receiving distilled water had no protection at all (Table 7).

\section{DISCUSSION}

Several plants possess therapeutic properties as a result of their phytochemical contents which are their principal active ingredients that serve as important sources for pharmaceutical research towards drug development (Edgar et al., 2002). Extracts from such investigated plants contain tannins, steroids, terpenoids, flavonoids, saponins and alkaloids that exhibit potent pharmacological activities (Duke, 1992; Mutalik et al., 2003).

Inflammation and pains are usually symptoms implicated in many various clinical presentations irrespective of the causative factors (Dhara et al., 2000). Several plant 
Table 6. Effect of water extract of $S L$ leaves on formalin-induced nociception in rats.

\begin{tabular}{lccc}
\hline Treatment & Dose $(\mathbf{m g} / \mathbf{k g})$ & Pain threshold score & \% inhibition \\
\hline Distilled water & $20 \mathrm{ml} / \mathrm{kg}$ & $2.8 \pm 0.37$ & 00.0 \\
& 100 & $2.4 \pm 0.24$ & $16.7^{\star}$ \\
S. lehmbachii & 200 & $0.8 \pm 0.37^{*}$ & $71.4^{\star}$ \\
& 400 & $0.4 \pm 0.40^{\star}$ & $85.7^{\star}$ \\
Aspirin & 150 & $0.2 \pm 0.20^{\star}$ & $92.9^{\star}$ \\
\hline
\end{tabular}

Data are expressed as mean \pm SEM $(n=6)$; ${ }^{*}$ significantly different from control at $p<0.05$.

Table 7. Effect of water extract of $S L$ leaves on mice tail immersion in $52 \pm 1^{\circ} \mathrm{C}$ hot water.

\begin{tabular}{|c|c|c|c|c|c|c|}
\hline \multirow{3}{*}{ Treatment } & \multirow{3}{*}{ Dose (mg/kg) } & \multicolumn{5}{|c|}{ Duration of stay (tail) in Hot Water (second) } \\
\hline & & \multicolumn{2}{|c|}{ Pretreatment } & \multicolumn{3}{|c|}{ After treatment } \\
\hline & & $0 \mathrm{~min}$ & $30 \mathrm{~min}$ & $60 \mathrm{~min}$ & $90 \mathrm{~min}$ & 120min \\
\hline \multirow[t]{2}{*}{ Distilled water } & $20 \mathrm{ml} / \mathrm{kg}$ & $6.53 \pm 0.30$ & $6.53 \pm 0.15$ & $6.58 \pm 0.21$ & $6.67 \pm 0.18$ & $6.63 \pm 0.00$ \\
\hline & 100 & $5.85 \pm 0.37$ & $7.33 \pm 0.23$ & $9.08 \pm 0.23$ & $9.21 \pm 0.72$ & $10.73 \pm 0.31^{*}$ \\
\hline \multirow[t]{2}{*}{ S.lehmbachii } & 200 & $5.87 \pm 0.28$ & $13.02 \pm 0.56^{*}$ & $13.27 \pm 0.33^{*}$ & $14.57 \pm 0.28^{*}$ & $17.23 \pm 0.55^{\star}$ \\
\hline & 400 & $6.08 .0 \pm 53$ & $14.28 \pm 0.53^{*}$ & $19.98 \pm 0.72^{*}$ & $21.17 \pm 0.60^{*}$ & $22.31 \pm 0.28 *$ \\
\hline Morphine & 10 & $5.89 \pm 0.34$ & $14.97 \pm 0.23^{*}$ & $20.36 \pm 0.51^{*}$ & $21.22 \pm 0.15^{\star}$ & $23.56 \pm 0.29 *$ \\
\hline
\end{tabular}

Data are expressed as mean \pm SEM $(n=6) ;{ }^{*}$ significantly different from control at $p<0.05$.

extracts or decoctions are used to relieve these symptoms in most traditional set-ups (Akuodor et al., 2011) - including water extract of S. lehmbachii leaves that are being studied scientifically. Salacia lehmbachii leaves in this study have exhibited significant antiinflammatory and analgesic activities.

Inflammatory reaction is complex and is characteristic responses by all living tissues. This phenomenon is brought about by various mediators like histamine, prostaglandins $E_{2}$ and $I_{2}$ that are synthesized as a result of the interaction of the noxious substances or microorganisms with the tissue (Barnes and Karin, 1998; Ganesh et al., 2008). The release of a cascade of other inflammatory mediators usually follows, making inflammatory reaction to involve both vascular and cellular components (Luster, 1998; Akuodor et al., 2015).

The water extract of $S$. lehmbachii leaves produced significant abolition/suppression of carrageenan and eggalbumin induced hind paw inflammatory oedema in the experimental Wistar rats. The induction of inflammatory reaction by these noxious substances are usually in two phases, starting with the early phase mediated via the release of histamine, kinins to the release of prostaglandins mediated by bradykinin, leukotrienes and polymorphonuclear from tissue macrophages. Induced arachidonate COX-2, prostaglandins and thromboxanes are usually involved in inflammatory process (Rang et al., 1999). This extract shows potent anti-inflammatory effect by abolishing the induced paw oedema similar to aspirin, which is a known potent NSAID. Hence, the mechanism of anti-inflammatory activity of $S$. lehmbachii leaves could be considered similar or via the inhibition of the any of the mediators involved in the inflammatory process. Albumininduced inflammatory reaction has biphasic response, the early phase emanating from the release of histamine, kinins and 5-HT; while the release of prostaglandins is implicated in the later phase via the release of bradykinin, leukotrienes and polymorphs induced from tissue macrophages (Rang et al., 1999; Jumping et al., 2005). The anti-inflammatory results shown by this extract were similar to standard drug, hence likely to act by inhibiting both early and late phases of inflammation.

Xylene-induced ear oedema experiment was used to further confirm the anti-inflammatory potential of this extract. Xylene is believed to irritate the mouse ear on its application, thereby causing inflammatory reaction with retention of fluid - oedema (Lin et al., 1992) and increase myloperoxidase enzyme activity (Ravelo et al., 2011; Essien et al., 2016b). This signified early sign of acute inflammatory reaction. The water extract of $S$. lehmbachii leaves produced significant percentage abolition of the ear oedema. Xylene produces inflammatory reaction via phospholipase $\mathrm{A}_{2}$ (Lin et al., 1992; Essien et al., 2016b); hence the activity of this extract could also be by inhibiting phospholipase $A_{2}$. This water extract of Salacia lehmbachii leaves contains phytochemicals such as steroids, flavonoids, alkaloids, saponins and others that are believed to be responsible for this potent antiinflammatory effect.

Pain symptom is a normal physiological response to any applied stimulus or by injecting noxious substance such as infective agents into the tissue or any cavity like 
peritoneal cavity. The manifesting symptom could be an increased muscle spasm or colicky pain resulting from increased activity of the released prostaglandins into peritoneal fluids (Deraedt et al., 1980; Akuodor et al., 2015) or other inflammatory mediators like bradykinin that possess potent spasmogenic activity in smooth muscles including GIT muscles as observed in this study when acetic acid is injected into peritoneal cavity.

Acetic acid-induced abdominal constriction method is widely accepted and used to elucidate peripheral analgesic effects of many compounds due to its simplicity and reliability (Singh and Majumbar, 1995; Akuodor et al., 2011). This study shows that acetic acid-induced abdominal constrictions in mice were significantly inhibited by the water extract of $S$. lehmbachii leaves. This analgesic action could be as a result of an inhibitory effect produced by prostaglandins via inhibition on the cyclo-oxygenase pathway which plays important role in the biosynthesis of prostaglandins, or/and attributable to the inhibition of the release of, or blockade of action of the endogenous mediators of pain, the prostaglandins. The analgesic activity exhibited by this water extract is similar to that of aspirin which is believed to possess both peripheral and central analgesia (Rang et al., 1999; Ravelo et al., 2011). Hence, the water extract of $S$. lehmbachii leaves could have similar action.

Tjolsen et al. (1992) reported that formalin can produce a distinct pain if injected into the tissue, hence, could be used in elucidating analgesic effect of extract and possible mechanism of their activity that could be either peripheral, or central or both (Breivik et al., 2008). Singh et al. 2008 reported that analgesic drugs acting centrally could elevate pain threshold. Therefore, Tail immersion test carried out shows that the water extract of $S$. lehmbachii leaves possess potent analgesic action by significantly protecting mice from heat stimuli of the hotbath, and elevating pain threshold of the experimental mice similar to that produced by Morphine. Morphine acts by inhibiting central nociceptive neurons (Laurence and Bennett, 1994), inhibits nociceptive spinal reflexes, thereby blocking the transmission of nociceptive impulses through the dorsal horn (Fields and Basbaum, 1994; Agbaje et al., 2008). The water extract could therefore have similar central mechanism of action.

Hollander-Hadacek (2002) and Mutalik et al. (2003) observed that plant extracts containing some flavonoids, steroids usually exhibit significant anti-inflammatory and analgesic effect. Hence, the anti-inflammatory and analgesic effects observed with this water extract of $S$. lehmbachii leaves may be attributable to phytochemicals such as flavonoids, steroids saponins and alkaloids present in the plant leaf extract. These findings show that plant leaves of Salacia lehmbachii could be a potential source for the development of substantial herbal painreliever. Further work to isolate and characterize the active ingredient(s) that is (are) responsible for the observed pharmacological activities of this plant's extract is on the way.

\section{Conclusion}

This present study has shown that the water extract of Salacia lehmbachii leaves possesses potent antiinflammatory and analgesic properties. The results help to justify the wide acceptable use of this plant in herbal practice for the treatment of fever and pains in Nigeria.

\section{Declaration of interest}

There is no conflict of interest among the contributing authors.

\section{ACKNOWLEDGMENT}

The authors are grateful to Mr. Marcus Inyang and Mr. Etim Ifang for laboratory assistance and other staffs of animal house for their immeasurable assistance.

\section{REFERENCES}

Agbaje, E. O., Adeneye, A. A., \& Adeleke, T. I. (2008). Antinociceptive and anti-inflammatory effects of a Nigerian polyherbal tonic tea (PHT) extract in rodents. Afr. J. Trad. Comp. Alt. Med., 5(3), 247-256.

Ahmad, M., Mehjabeen, Zia-Ul-Haq, M., \& Jahan, N. (2011). Determination of $L D_{50}$ and $E D_{50}$ by dose relationship and assessment of toxicological and non-toxicological behavior of Ipomoea hederacea. J. Pharmacol., 4(4), 1176-1178.

Akah, P. A., \& Nwabie, A. (1994). Evaluation of Nigeria traditional medicine 1: plants used for rheumatic (inflammatory) disorders. J. Ethnopharmacol., 42, 179-182.

Akuodor, G. C., Anyalewechi, N. A., Udoh, F. V., Ikoro, N. C., Akpan, J. L., Gwotmut, M. D., Iwuanyanwu, T. C., \& Osunkwo, U. A. (2011). Pharmacological evaluation of Verbena hastate leaf extract in the relief of pain and fever. Adv. Pharmacol. Toxicol., 12(3), 1-8.

Akuodor, G. C., Essien, A. D., Udia, P. M., David-Oku, E., Chilaka, K. C., Asika, E. C., \& Nwadum, S. K.. (2015). Analgesic, anti-inflammatory and antipyretic potential of the stem bark of Stachytarpheta indica. Br. J. Pharmacol. Toxicol., 6(1), 16-21.

Al-Ghamdi M. S. (2001). Anti-inflammatory, analgesic and antipyretic activity of Nigella sativa. J. Ethnopharmacol., 76, 45- 48.

Bachhav, R. S., Gulecha, V. S., \& Upasani, C. D. (2009). Analgesic and anti-inflammatory activity of Argyrela speciosa root. Indian J. Pharmacol., 41(4), 158-161.

Barnes, P. J., \& Karin, M. (1998). Nuclear factors-kB -a pivotal transcription factor in chronic inflammatory diseases. N. Engl. J. Med., 336, 1066-1071.

Breivik, H., Borchgrevink, P. C., Allen, S. M., Rosseland, L. A., Romunstad, L., \& Hals, E. K. (2008). Assessment of pains. Br. J. Anaesthesia., 101(1), 17-24.

Dhara, A. K., Sube, V., Sen, T., Pal, A. N., \& Chandhiri, A. K. (2000). Preliminary studies on anti-inflammatory and analgesic activity of the methanolic fractions of the root extract of Tragia involucrate. J. Ethnopharmacol., 72, 265-268. 
Deraedt, R., Jongney, S., Delevalcee, F., \& Falhout, M. (1980). Release of prostaglandin $E$ and $F$ in an analgesic reaction and its inhibition. Eur. J. Pharmacol., 51, 17-24.

Duke, J. A. (1992). Hand book of Biologically Active Phytochemical and the Activities. CRC Press. Boca, Raton, FL. USA.

Edgar, J. D., Elias, B., \& Adnah, B. (2002). Biotechnology and the developing world. Electronic J. Biotechnol., 5(1), 137-142.

Elujoba, A. A., Odeleye, O. M., \& Ogunyemi, C. M. (2005). Traditional medicinal development for medical and dental primary health care delivery system in Africa. Afr. J. Trad. Complement. Alt. Med., 2, 46-61.

Essien, A. D., Akuodor, G. C., Essien, E. A., Asika, A. C., Chilaka, K. C., \& Nwadum, S. K. (2015a). Evaluation of antipyretic potential of the ethanolic leaf extract of Salacia lehmbachiiLoes. Asian J. Med. Sci., 7(2), 22- 25.

Essien, A. D., Lapah, P. T., \& Emmanuel, I. A. (2015b). In vitro cholinergic and acute toxicity of Salacia lehmbachii. International Journal of Pharmacy and Pharmaceutical Research, 5(1), 200-207.

Essien, A. D., Essiet, G. A., Akuodor, G. C., Aja, D. O. J., Thomas, E. E., Nwadike, K. I., Nwachukwu, D. C., \& Chilaka, K. C. (2016a). Studies on gastrointestinal properties of ethanolic leaf extract of Salacia lehmbachii in Wister rats. Afr. J. Pharmacy Pharmacol., 10(20), 451-457.

Essien, A. D., Essiet, G. A., Akuodor, G. C., Akpan, J. L., Chilaka, K. C., Bassey, A. L., Ezeokpo, B. C., \& Nwobodo, N. N. (2016b). Pharmacological evaluation of the aqueous stem bark extract of Bombax buonopozense in the relief of pain and fever. Afr. J. Pharmacy Pharmacol., 10(5), 59-65.

Essiet, G. A., Takem, L. P., Essien, A. D., Akuodor, G. C., \& Udoh, F. V. (2016a). Investigation of hepatic toxicity of Salacia lehmbachii. International Journal of Pharmacy and Pharmaceutical Research, 6(2), 95-103.

Essiet, G. A., Essien, A. D., Takem, L. P., Akuodor, G. C., \& Udoh, F. V. (2016b). Hematological changes following oral administration of aqueous root bark extract of Salacia lehmbachii in albino rats. Int. Blood Res. Review, 6(1), 1-8.

Fields, H. L., \& Basbaum, A. I. (1994). Central Nervous mechanisms of pain modulation. In: Wall, P. D., Melzack R., (ed.) Text book of Pain. Elsevier/Churchill Livingstone, Edinburgh.

Ganesh, M., Vasudevan, M., Kamalakaman, K., Kamar, A. S., Vinoba, M., Gaguly, S., \& Sivakumar, T. (2008). Antiinflammatory and analgesic effects of Pongamia glabra leaf gall extract. Pharmacol. Online, 1, 497-512.

Ghosh, M. N. (2005). Fundamental of Experimental pharmacology. India: Scientific Book Agency. Calcutta. Pp. 69-71.

Hakiman, M., \& Maziah, M. (2009). Non enzymatic and antioxidant activities in aqueous extract of different Ficudeltoidea accessions. J. Med. plant Res., 3(3), 120-131.

Hollander-Hadacek, F. (2002). Secondary metabolites as plant traits: Current assessment and future perspectives. Crit. Rev. plant Sci., 21, 273- 322.

Hosseinzedeh, H., \& Younesi, H. M. (2002). Anti-nociceptive and anti-inflammatory effects of Crocus sativus $L$ stiga and petal extracts in mice. BMC Pharmacol., 2(7), 1471-2210.

Huffman, M. A. (2003). Animal self-medication and ethnomedicine exploration and exploitation of the medicinal properties of plants (in Hindu). Proc. Nutr. Soc., 62(2), 371381.
Jumping, K., Yun, N., Wang, N., Liang, I., \& Zhi-Hong, H. (2005). Analgesic and anti-inflammatory activities of total extract and individual fractions of Chinese medicinal plant Polyrrchasis lamellidens. Biol. Pharmaceut. Bull., 28, 176180.

Lai, P. K., \& Roy, J. (2004). Antimicrobial and chemo-preventive properties of herbs and spices. Curr. Med. Chem., 11(11), 451-460.

Laurence, D. R., \& Bennett, P. N. (1994). Clinical Pharmacology. $7^{\text {th }}$ ed. ELBS Churchill Livingstone. UK.

Lin, L. L., Lin, A. Y., \& Knopt, J. L. (1992). Cytosolic phospholipase $A_{2}$ is coupled to hormonally regulated release of arachidonic acid. Proc. Natl. Acad. Sci., 89, 6147-6517.

Luster, A. D. (1998). Mechanisms of disease: ChemokinesChemotactic cytokines that mediate inflammation. N. Engl. J. Med., 338, 436-445.

Mukherjee, P. R. (2006). Quality Control of Herbal Drugs, an approach to Evaluation of Botanicals. $13^{\text {th }}$ Ed., Business Horizones Publishers, New Delhi. Pp. 419-459.

Mutalik, S., Paridhavi, K., Mallikarjuna, R. C., \& Udupa, N. (2003). Antipyretic and analgesic effect of leaves of Solamummelongena Linn in rodents. Indian J. Pharmacol., 35, 312-315.

OECD (2010). Guidelines for the testing of chemicals. Testing no. 423 acute oral toxicity. Acute Toxicity Class. Method. 1(4), 1- 14.

Okokon, J. E., \& Nwafor, P. A. (2010). Anti-Inflammatory, Analgesic and Antipyretic activities of ethanolic root extract of Croton zambesicus. Pak. J. Pharm. Sci. 23(4), 385-392.

Ramabadran, K., Bansinath, M., Turndorf, H., \& Puig, M. H. (1989). Tail immersion test for the evaluation of nociceptive reactions in mice. J. Pharmacol. Methods, 21(1), 21-31.

Rang, H. P., Dale, M. M., \& Ritter, J. M. (1999). Pharmacology. Churchill Livingstone; $4^{\text {th }}$ edit. Pp. 198-602.

Ravelo, Y., Molina, V., Carbajal, D., Fernandez, L., Fernandez, J., Arruzazabala, M. L., \& Mas, R. (2011). Evaluation of antiinflammatory and anti-nociceptive effects of D-002 (beeswax alcohols). J. Nat. Med. 65(2), 330-335.

Singh, A., Malhotra, S., \& Subban, R. (2008). Anti-inflammatory and analgesic agents from Indian medicinal plants. Int. $J$. Integr. Biol., 3(1), 57-60.

Singh, S. D., \& Majumbar, K. (1995). Analysis of activity of Olimum sanctum and its possible mechanism of action. Int. J. Pharmacol., 3, 188-192.

Sofowora, A. (1993). Medicinal Plants and Traditional Medicine in Africa. Spectrum Books, Ibadan. p. 150.

Tapsel, L. C., Hemphil, A., \& Cobiac, L. (2006). Health benefits of herbs and spices: The past, the present and the future. Med. J. Austr., 185(4), 24-54.

Tjolsen, A., Berge, O. G., Hunskaar, S., Rasland, J. H., \& Hole, K. (1992). The formalin test: An evaluation of method. Pain. 51, 5-17.

WHO (2006a). Guidelines for the treatment of malaria, Geneva. Willcox, M. L., \& Bodeker, G. (2004). Clinical review: Traditional herbal medicines for malaria. BMJ, 329, 11561163.

Xu, Q., Wang, Y., Guo, S., Shen, Z., Wang, Y., \& Yang, L. (2014). Anti-inflammatory and analgesic activity of water extract of Flospopuli. J. Ethnopharmacol., 152(3), 540-545. 